\title{
FIRST SEXUAL MATURATION AND BREEDING CYCLE OF Pangasius Hypophthalmus (SILURIFORMES, PANGASIIDAE) REARED IN POND
}

\author{
Anang Hari Kristanto"), Jacques Slembrouck"*), and Marc Legendre*)
}

\begin{abstract}
The age and weight at first sexual maturation and the seasonal variations of sexual maturity of Pangasius hypophthalmus were determined on a fish group spawned in April 1997 and followed up until 32 months of age at the Sukamandi RIFF Station, west Java Indonesia. The fishes used for the study were initially obtained by hormone-induced breeding. At one month of age, 300 fingerlings of $0,8 \pm 0,5 \mathrm{~g}$ mean body weight were stocked in a $400 \mathrm{~m}^{2}$ earthen pond. The fishes were fed to a $35 \%$ crude protein pelleted feed distributed at a daily rate decreasing progressively from 10 to $2 \%$ of fish biomass during the first 7 months of rearing. Every month, 30 individual of fish were by one measured for standard and total length and weighed. In order to follow the gonad development and the temporal evolution of sexual maturity about 10 of the sampled fish ( 2 to 7 females and 3 to 5 males) were killed, dissected and their gonads weighed for calculation of the gonadosomatic indexes (GSI). The fat deposited in the abdominal cavity was also weighed to follow the temporal evolution of the adipo-somatic index (ASI). Starting when females were 21 months of age, their fecundity was estimated by counting all oocytes belonging to the most advanced modal group, in two samples (1 gram each) of the ovaries fixed in $5 \%$ formalin. The result showed that males of $P$. hypothalmus were sexually mature after 10 months of age $(472 \pm 78 \mathrm{~g}$ mean BW) while females matured much later, after 19 months of age $(2,249 \pm 279 \mathrm{~g}$ mean $\mathrm{BW})$. The monthly mean ASI varied between $0.1 \%$ and $1.3 \%$ in both males and females. The monthly evolution of GSI showed the occurrence of seasonal variations in the intensity of sexual activity. Once the fish had reached sexual maturity, the monthly mean GSI of males varied between $0.6 \pm 0.2 \%$ and $9.0 \pm 1.0 \%$ and that of females between $3.0 \pm 1.1 \%$ and $20.9 \pm 0.1 \%$, depending on season. For both sexes, the highest GSI values were found during the rainy season, from November to March, and the lowest during the dry season from May to August. The temporal evolution of relative fecundity followed that of GSI. The minimal mean fecundity, 49,000 $+38,000$ eggs. $\mathrm{kg}-\mathrm{I}$, was observed in July 1999 and the highest one, 372,000 $\pm 19,000$ eggs. kg-l, in November 1999 . By contrast, the monthly mean diameter of the most developed oocyte group in the ovaries showed smaller temporal changes, varying between $0.97 \pm 0.07 \mathrm{~mm}$, in June, and $1.14 \pm$ $0.01 \mathrm{~mm}$, in November. Even during the dry season individual males with intratesticular sperm and females with postvitellogenic oocytes (diameter $>1 \mathrm{~mm}$ ), apt to ovulate after hormonal treatment, were found. hypophthalmus fry was possible.
\end{abstract}

KEYWORDS:

sex maturation, breeding cycle, season, Pangasius hypophthalmus

\section{INTRODUCTION}

Pangasius hypophthalmus is a catfish of the Pangasiidae family, belonging to the Pangasius genus. This fish is original from Thailand and distributed to the other area such as Malaysia, Indonesia, and China. P. hypophthalmus (Sauvage, 1878 senior synonym of $P$. sutchi, Roberts \& Vidthayanon, 1991) is the important economic freshwater species in South East Asia. The first success of induced breeding of $P$. hypophthalmus in Indonesia was occurred in 1981 (Hardjamulia et al., 1981). Since than, most research was focused on the larval rearing aiming at increasing the number of survivor rate. The published data related to its biology and cultures are still rare. In term of induced breeding, Potaros \& Sitasit (1976) mentioned that the spawning season of $P$. hypophthalmus was between June and September in Thai climic conditions, while Saidin \& Othman (1986) reported broodstock matured from June to December in Malaysia ponds. Hardjamulia et al., (1981) also reported that females $P$. hypophth/mus were sexually mature during the rainy season, from October to April. Legendre et al., (1999) also reported maturation of both sexes of $P$. hypophthalmus were observed even during the dry season in the ponds of the Sukamandi station located in West Java.

The experiment was aimed to observe the first sexual maturation of male and female $P$. hypophthalmus in rearing pond, to observe the fluctuation of gonado somatic index (GSI) and adipo somatic index (ASI) during rearing period in relation to water temperature and rain falls and to test for possible variations of fecundity or egg size in relation to season.

\section{MATERIALS AND METHODS}

The fish broodstock were held in the ponds at the Sukamandi Station of Research Institute for Freshwater Fisheries Indonesia. This area has generally two distinct climates, dry season from May to September and rainy season from October to April. The range of day length variation was about 30 minutes.

\footnotetext{
Research Institute For Freshwater Agriculture, Ministry of Marine Affairs and Fisheries, Bogor

IRD, Institute de Recherche pour le Developpement, France
} 
The fishes used for the study were initially obtained by hormone-induced breeding. At 1 month of age, 300 fingerlings of $0,8 \pm 0,5 \mathrm{~g}$ mean body weights were stocked in a $400 \mathrm{~m}^{2}$ earthen pond. The fish was fed to $35 \%$ crude protein pelleted feed distributed at a daily rate decreasing progressively from 10 to $2 \%$ of fish biomass during the first 7 months of rearing. Every month, 30 individual of fish were measured for standard and total length and weighed. To follow the gonadal development and the temporal evolution of sexual maturity about 10 of the sampled fish ( 2 to 7 females and 3 to 5 males) were sacrificed, dissected and their gonads weighed for calculation of the gonado-somatic indexes (GSI). The fat deposited in the abdominal cavity was also weighed to follow temporal evolution of the adiposomatic index (ASI). Starting when females were 21 months of age, their fecundity was estimated by counting all oocytes belonging to the most advanced modal group, in two samples (1 gram each) of the ovaries fixed in $5 \%$ formalin. The water temperature was recorded every day and the rainfall data was obtained from the RIFSR (Research Institute For Swampy Rice) at Sukamandi, West Java

The GSI and ASI calculation were followed:

$$
\begin{aligned}
& D S I=\frac{\text { Weight of gonad }(g)}{\text { Weight of fish with the gonad }(g)}(\text { Weffendi, 1985) } \\
& A S I=\frac{\text { Weight of fat }(g)}{\text { Weight of fish }(g)} \quad(\text { Effendi, 1985) }
\end{aligned}
$$

Fecundity $=$ Weight of gonad $(\mathrm{g}) \times$ number of eggs/gram sample (Bagenal, 1968)

The data were analyzed in descriptive manner and figured.

\section{RESULT}

$P$. hypothalmus males were sexually mature after 10 months of age $(472 \pm 78 \mathrm{~g}$ mean BW) while females matured much later, after 19 months of age $(2,249 \pm 279 \mathrm{~g}$ mean BW). The monthly mean ASI varied between $0.1 \%$ and $1.3 \%$ in both males and females. The maximal ASI values were observed before GSI values started to increase suggesting a mobilization of fat reserves during the process of gonad development. The monthly evolution of GSI showed the occurrence of seasonal variations in the intensity of sexual activity. Once the fish had reached sexual maturity, the monthly mean GSI of males varied between $0.6 \pm 0,2 \%$ and $9.0 \pm 1.0 \%$ and that of females between $\overline{3} .0 \pm 1.1 \%$ and $20.9 \pm 0.1 \%$, depending on season. For both sexes, the highest GSI values were found during the rainy season, from November to March, and the lowest during the dry season from May to August. The average of water temperature was relative stable even the amount of rainfall fluctuated yearly. Water temperature ranged between $28-31^{\circ} \mathrm{C}$. Relationship between water temperature, rainfall and variation of gonadosomatic index (GSI) and adipo somatic index (ASI) is presented in Figure 1.

The temporal evolution of relative fecundity followed that of GSI. The minimal mean fecundity, $49,000 \pm 38,000$ eggs.kg-1, was observed in July 1999 and the highest one, $372,000 \pm 19,000$ eggs. $\mathrm{kg}$ 1 , in November 1999. By contrast, the monthly mean diameter of the most developed oocyte group in the ovaries showed smaller temporal changes, varying between $0.97 \pm 0.07 \mathrm{~mm}$, in June, and $1.14 \pm 0.01$ $\mathrm{mm}$, in November. Even during the dry season individual males with intratesticular sperm and females with postvitellogenic oocytes (diameter $>1$ $\mathrm{mm}$ ), apt to ovulate after hormonal treatment, were found. The seasonal variation of GSI value of female $P$. hypophthalmus and the relationship with the fecundity and modal diameter was presented in Figure 2.

\section{DISCUSSION}

Timing and success of teleost reproduction are directly or indirectly controlled by environmental factors such as temperature and photoperiod. Environmental condition influences gonadal activity in fish through the mediation of the hypothalamus-pituitary-gonad axis, which result in endocrine fluctuation (Crim, 1982). Environmental cues for the reproduction of fish vary according to the spawning season and different geographic locations.

Water temperature is one of the most important environmental factors affecting the reproductive cycle. Increasing water temperature induces early maturation of summer spawning species such as Sillago sihama (Lee, 1985). Effect of water temperature on $P$. hypophthalmus and $P$. bocourti maturation was observed by Cacot (1999) suggesting that $P$. hypophthalmus requires higher temperature and/or longer daytime than $P$. bocorti to start sexual maturation. In red drum and spotted sea trout, temperature had a profound effect on spawning frequency, spawning decreased when water temperature were below $25^{\circ} \mathrm{C}$ and ceased altogether below $20^{\circ} \mathrm{C}$. Legendre et al., (1998) reported that $P$. hypophthalmus reared in ponds at Sukamandi Station, the oocyte development did not show such yearly evolution as the average oocyte diameter stands high throughout the year. Females were able to reproduce three to four times per year. The environment in this subequatorial area is relatively stable as the temperature stands high, ranging from 28 to $31^{\circ} \mathrm{C}$, the photoperiod range only half and hour and the rainy season was little marked. Other result describing effect of water temperature on gonadal development was found in rose bitterling Rhodeous ocellatus 

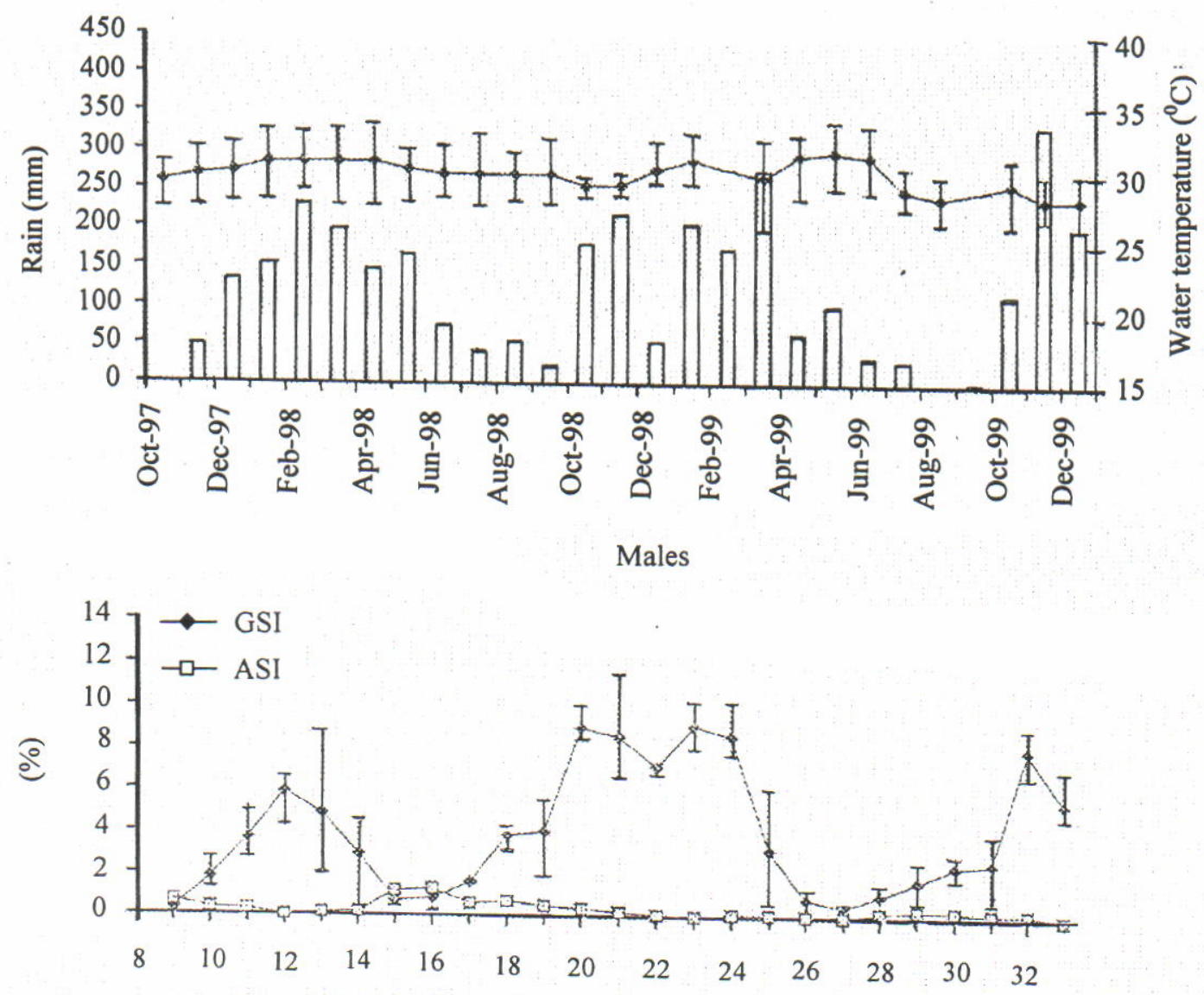

Females

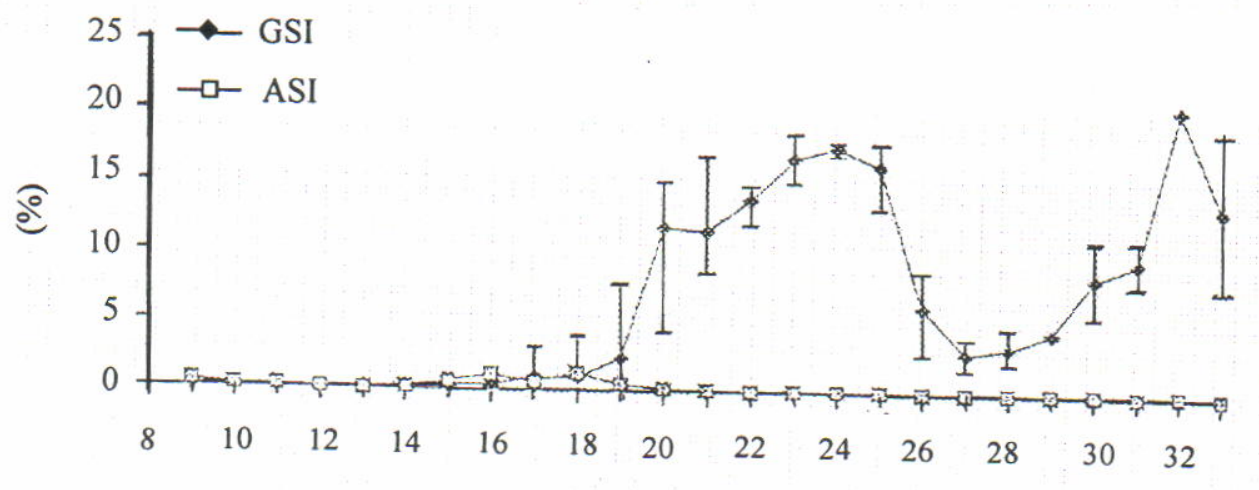

Age (month)

Figure 1. Seasonal variation of gonado somatic index and adipo somatic index of males and females $P$. hypophthalmus reared in Sukamandi pond in relation to the water temperature and rainfall 

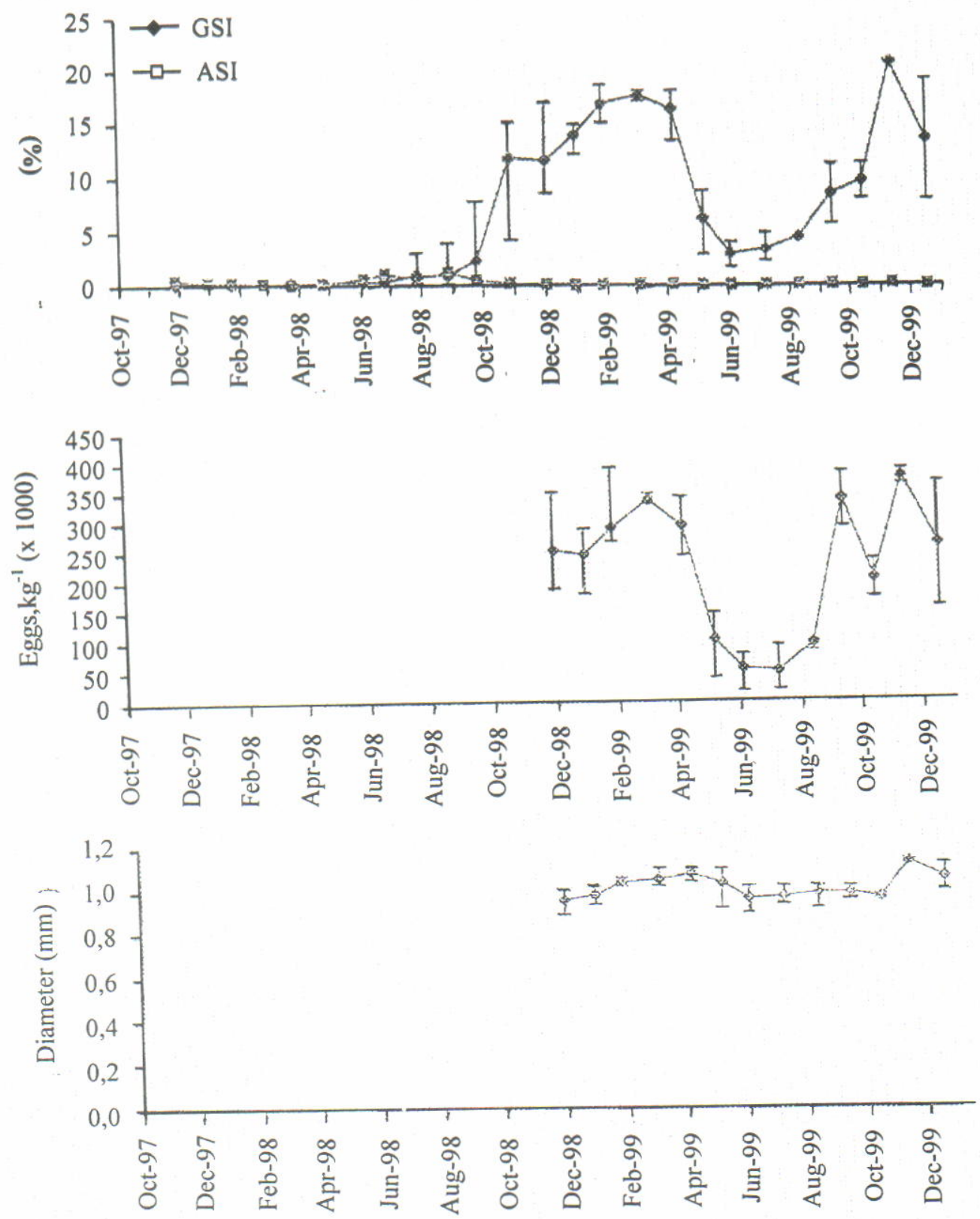

Figure 2. Variation of fecundity (eggs $/ \mathrm{kg}$ ) and eggs diameter in relation to the gonado somatic index of female $P$. hypophtalmus reared in Sukamandi pond.

ocellatus. The female GSI showed a sudden rise in March, a plateu and then an abrupt in September while water temperature range was 16 to $22^{\circ} \mathrm{C}$ (Asahima \& Hanyu, 1983).

On the present study demonstrated that the GSI value varied at each month following the water temperature and rainfall, and the lowest value was at June and July during the dry season. Both female and male after first sexual maturation reached matured all year long with post-vitellogenic oocytes modal diameter superior to $1.00 \mathrm{~mm}$ at anytime. This study in also supported the result obtained from the previous research conducted by Legendre et al., (1998).

\section{CONSCLUSION}

This study demonstrated that gonadal maturation was related to water temperature and rainfall. $P$. hypothalmus males were sexually mature after 10 months of age $(472 \pm 78 \mathrm{~g}$ mean BW) while females matured much later, after 19 months of age (2249 \pm 
$279 \mathrm{~g}$ mean $\mathrm{BW})$. On the pond water temperature ranged from $28^{\circ} \mathrm{C}-31^{\circ} \mathrm{C}$, mature females $P$. hypothalamus with eggs of diameter $>1 \mathrm{~mm}$ were found during the dry and rainy season. It is implied that induced breeding of $P$. hypophthalmus using hormonal treatment could be performed regardless the season and allowed an all-yearlong production.

\section{REFERENCES}

Asahina, K. \& 1. Hanyu. 1983. Role of temperature and photoperiod in annual reproductive cycle of the rose bitterling Rhodeus ocellatus ocellatus. In Reproduction and culture of milkfish. Edited by Cheng Sheng Lee and I Chiu Liao. Oceanic Institute and Tungkang Marine Laboratory.

Bagenal, T.B. 1968. Methods for assessment of fish Production. IBP. Black Well Scientific Production. 159-181.

Crim, L. W. 1982. Environmental modulation of annual and daily rhythm associated with reproduction in teleost fishes. Can. 1. Fish. Aquat. Sci. 39:17-21.

Effendi, M.I. 1985. Biologi Perikanan. Fakultas Perikanan. IPB. Bogor, Indonesia.

Hardjamulia, A., Djajadiredja R., Atmawinata S., \& Idris D. 1981. Pembenihan jambal siam Pangasius sutchi dengan suntikan ekstraks kelenjar hipofise ikan mas Cyprinus carpio. Buletin Penelitian Perikanan Darat. Balai Penelitian Perikanan Darat, Bogor, Indonesia. 183-190
Legendre, M., J. Subagja \& 1. Slembrouck. 1998. Absence of Marked seasonal variations in sexual maturity of Pangasius Hypophthalmus held in ponds at the Sukamandi Station (Java, Indonesia). Proceeding of the mid-term workshop of the Catfish Asia Project. Cantho, Vietnam, 11-15 May 1998.

Lee, C.S. \& R Hirano. 1985. Effects of water temperature and photoperiod on the spawning cycle of sand borer, Sillago sihama (Forsskal). The Prog. Fish-culturist 47(4).

Potaros M. \& Sitasit, P. 1976. Induced spawning of Pangasius sutchi (Fowler). FAO,IPFC/76/SYM/ $36,17,349-35$

Roberts T.R. \& Vidthayanon C. 1991. Systematic revision of the Asian catfish family Pangasiidae, with biological observations and descriptions of three new species. Proceeding of the Academy of Natural Sciences of Philadelphia, 143, 97-143

Saidin, T. \& Othman, A.F. 1986. Induced spawning of Pangasius suthi (Fowler) using analog of luteinizing releasing hormone and homoplastic pituitary extract. In Legendre, M., J. Subagja \& J. Slembrouck. 1998. Absence of Marked seasonal variations in sexual maturity of Pangasius Hypophthalmus held in ponds at the Sukamandi Station (Java, Indonesia). Proceeding of the midterm workshop of the Catfish Asia Project. Cantho, Vietnam, 11-15 May 1998. 
